\title{
Correction to: Inviting critical political economy to the table
}

\author{
Toby Miller ${ }^{1,2}$
}

Published online: 2 December 2020

(C) Springer Nature B.V. 2020

\section{Correction to: Climatic Change https://doi.org/10.1007/s10584-020-02937-6}

The original article has been updated. Unfortunately, the article was published with an incorrect title. This has been corrected to Inviting Critical Political Economy to the Table.

Publisher's note Springer Nature remains neutral with regard to jurisdictional claims in published maps and institutional affiliations.

The online version of the original article can be found at https://doi.org/10.1007/s10584-020-02937-6

Toby Miller

tobym69@icloud.com

1 Universidad Autónoma Metropolitana-Cuajimalpa, Mexico City, Mexico

2 Murdoch University, Perth, Australia 